Nama : Muthia Zhafirah Ali

NIM : 90100118037

Kelas : Ekonomi Islam A

\title{
KONSEP EKONOMI PADA MASA DINASTI
}

Seorang pemimpin adalah seorang yang sangat berperan penting dalam kemajuan suatu negara. Karena manusia merupakan khalifah di muka bumi ini untuk menciptakan rahmat bagi seluruh manusia dan menjadikan sebuah negara menjadi lebih baik. Setelah kepemerintahan dipimpin oleh khalifah kemudian dilanjutkan oleh kepemerintahan dinasti yang terdiri atas Bani Umayyah, Bani Abbasiyah dan Turki Utsmani. (Annisa \& Ghozali, 2019)

\section{Bani Umayyah}

Setelah wafatnya khalifah Ali bin Abi Thalib kepemerintahan dilanjutkan oleh Bani Umayyah. Pemerintahan pada zaman Bani Umayyah dibagi atas 3. Yang pertama yakni dipimpin oleh khalifah Muawiyyah bin Abi Sofyan. Pada masa pemerintahannya, khalifah Muawiyyah bin Abi Sofyan mencetak uang, membangun dinas sekaligus fasilitasnya dan menertibkan angkatan perang. Muawiyyah bin Abi Sofyan juga memberikan gaji kepada para tentara. Kemudian dilanjutkan kepemerintahan Abdul Malik bin Marwan. Yang dimana perkembangan perdagangan membawa masyarakat kepada kemakmuran dan pemerintahannya naik ke taraf yang menakjubkan. Selain itu beliau juga mencetak uang dan mencantumkan Bismillahirrohmanirrohim terhadap mata uang kemudian disebarkan ke seluruh wilayah Islam.

Dan yang terakhir kepemerintahan dilanjutkan oleh Umar bin Abdul Aziz. Pada masa pemerintahannya, Umar bin Abdul Aziz mengumpulkan rakyatnya dan memberikan seluruh kekayaannya beserta harta keluarganya untuk disumbangkan kepada kaum muslimin melalui Baitul Mal. Beliau juga mengeluarkan kebijakan pembukaan jalur perdagangan di darat maupun di laut untuk meningkatkan taraf kehidupan masyarakat. 
Sumber-sumber penghasilan pada masa ini yakni cenderung dari zakat, harta rampasan perang dan pajak penghasilan pertanian. (Huda, 2020)

\section{Bani Abbasiyah}

Pemerintahan Bani Abbasiyah merupakan pemerintahan yang dilanjutkan setelah kepemerintahan Bani Umayyah. Pada awal masa pemerintahan Bani Abbasiyah dipimpin oleh Abu Ja'far Al-Mansur. Kebijakan yang dikeluarkan oleh Abu Ja'far Al-Mansur yakni penertiban administrasi birokrasi, bersikap keras dalam peneguhan kedudukan keuangan negara dan beliau juga hemat membelanjakan uang negara. Selain itu kepemerintahannya dikenal edengan figur politiknya yang sangat kuat dan begitu dominan. Di zaman Abu Ja'far Al-Mansur juga perkembangan ilmu sangat pesat sehingga Bani Abbasiyah mencapai zaman keemasan atau bisa disebut dengan "The Golden Age". Karena pada saat itu umat muslim sudah mencapai tingkat ekonomi yang stabil, berkembangnya ilmu pengetahuan dan pertanian, kekuasaan dan peradaban serta masuknya penerjemahan bukubuku dari bahasa asing ke bahasa arab. Disamping kemajuan Bani Abbasiyah pada saat itu Abu Ja'far Al-Mansur juga sering menumpahkan darah kepada orang-orang yang bekerja yang tidak sesuai dengan keinginannya. Setelah kepemerintahan Abu Ja'far Al-Mansur dilanjutkan oleh Harun Ar-Rasyid. Beliau memiliki beberapa kebijakan yakni diversifikasi sumber pendapatan negara serta konsen kepada perpajakan yakni Al-Muhassabah, AlMuqasamah, Al-Muqqatha'ah. (Meriyati, 2018)

\section{Turki Utsmani}

Turki Utsmani diberikan julukan sebagai pusat khalifah Islam karena pada saat itu pemerintahan Islam menjadi yang terkuat bahkan merupakan negara paling besar di dunia. Menurut Akbar S. Ahmad peran Turki Utsmani sangat penting karena mereka menjabat pada masa pemerintahan yang terlama dan menjadi yang terbesar. Kepemerintahan Turki Utsmani maju semenjak Sultan Mahmud II menjabat pada tahun 1453. Beliau berhasil menaklukan Byzantium Romawi sehingga menjadikan negara Turki sebagai negara yang perlu diperhatikan dan diperhitungkan oleh para pakar di Eropa. Pada masa Turki Ustmani juga diterapkan beberapa kebijakan lainnya seperti desertralisasi pengaturan pajak, kebijakan dalam bidang pertanian dan melakukan efisiensi pengeluaran. Sehingga dapat 
disimpulkan bahwa kerajaan Turki Utsmani merupakan kerajaan yang mampu bertahan selama 20 abad dan lebih memfokuskan kepada permasalahan perluasan wilayah dan militer. Maka dari itu berkaitan dengan praktek pendidikan dan kehidupan intelektualnya secara keseluruhan diarahkan untuk memperkokoh kualitas kerajaannya. (Abi Suar, 2020) 


\section{DAFTAR PUSTAKA}

Huda, M. N. (2020). Sejarah Pemikiran Ekonomi Islam Pada Masa Daulah Bani Umayyah dan Bani Abbasiyah. EOSTORIA, 1(01), 94-105.

Silvi, K. A., Ghozali, M. (2019). Konsep Welfare State Pada Kebijakan Umar Bin Abdil Aziz Sebagai Khalifah Bani Umayyah. Laa Maisyir, 6(2), 283.

Meriyati. (2018). Perkembangan Ekonomi Islam Pada Masa Daulah Abbasiyah. Islamic Banking, 4(1), 47-55.

Suar, Abi. (2020). Pemikiran Ekonomi Islam Pada Masa Awal Turki Utsmani. Al-Dzahab, 1(1), 53-71. 